\title{
Klutiana brevigenalis sp. $n$., a new species of Nesomesochorinae from the Afrotropical region (Hymenoptera: Ichneumonidae)
}

\author{
ZOLTÁN VAS \\ Hungarian Natural History Museum, Department of Zoology, \\ H-1088 Budapest, Baross utca 13, Hungary \\ E-mail:vas.zoltan@nhmus.hu
}

\begin{abstract}
As a recent result of the ongoing identification process of Ichneumonidae material in the Hymenoptera Collection of the Hungarian Natural History Museum, Klutiana brevigenalis sp. n., a new species of Ichneumonidae: Nesomesochorinae is described from Tanzania. An identification key to the Afrotropical species of Klutiana Betrem, 1933 is given. With two figures.
\end{abstract}

Key words - taxonomy, species description, Tanzania, Hungarian Natural History Museum

\section{INTRODUCTION}

Klutiana Betrem, 1933 is small genus of subfamily Nesomesochorinae, family Ichneumonidae, with 16 known species worldwide, of which 13 species are known from the Oriental region only, two from the Eastern Palaearctic region only, one from both regions, and one species from the Afrotropical region (QUICKE et al. 2005, YU et al. 2012). As a recent result of the ongoing identification process of Ichneumonidae material in the Hymenoptera Collection of the Hungarian Natural History Museum (HNHM, Budapest), a new Afrotropical species of Klutiana has been found in the material of a HNHM collecting trip in Tanzania in 1987 (MAHUNKA et al. 1987). In this paper Klutiana brevigenalis sp. n. is described, and an identification key to the Afrotropical species of the genus is given.

Ichneumonidae taxonomy and nomenclature follow YU \& HORSTM ANN (1997) and YU et al. (2012). Morphological terminology follows GAULD (1991) and GAULD et al. (1997); however, in the cases of wing veins the corresponding terminology of Townes (1969) is also indicated. Identifications were based on SEYRIG (1935), Townes (1970), Townes \& Townes (1973) and Gupta (1980). The specimens were identified by the author using a Nikon SMZ645 stereoscopic microscope. Photos were taken by the author with a $14 \mathrm{MP}$ MicroQ-U3L digital camera. Postimage work was done with ToupTek ToupView v4.7 and Photoshop CC. 


\section{RESULTS \\ Subfamily: Nesomesochorinae Ashmead, 1905 \\ Genus: Klutiana Betrem, 1933}

Type species: Klutiana compressa Betrem, 1933; monobasic.

syn.: Mavandiella Seyrig, 1935; type species: Mavandiella hemitelina Seyrig, 1935; original designation.

\section{Klutiana brevigenalis sp. $\mathbf{n}$.}

(Figs 1-2)

Type material - Holotype: female, Tanzania, Tanga region, Amani, Botanical Garden, 13.II.1987, leg. S. Mahunka \& A. Zicsi, No. 127, swept; specimen cardmounted, broken parts of fore legs glued to card, apex of right antenna missing; Id. No. HNHM-HYM 155049; deposited in HNHM, Budapest.

Diagnosis - The new species can be easily identified by the following character states in combination: gena conspicuously short and narrowed behind eyes, in dorsal view $0.2 \times$ as long as eye width, in lateral view $0.05-0.1 \times$ as long as eye width; sternaulus short and relatively weak, not reaching middle of mesopleuron; intercubitus (2rs-m) about as long as abscissa of $M$ between $2 r s-m$ and $2 \mathrm{~m}-\mathrm{cu}$; second tergite relatively stout, ca. $2.5 \times$ as long as its apical width; ovipositor apex distinctly downcurved; metasoma and hind leg brown.

Description - Female (Figs 1-2). Body length ca. $5 \mathrm{~mm}$, fore wing length ca. $3 \mathrm{~mm}$.

Head: Antenna with 23 flagellomeres; first flagellomere very long and slender, $6 \times$ as long as its apical width; preapical flagellomeres longer than wide. Head transverse, lenticular, shiny, very finely coriaceous to almost smooth, without punctures; hairs sparse and short, on lower face and clypeus hairs somewhat longer and denser. Ocular-ocellar distance $1.4 \times$ as long as ocellus diameter, distance between lateral ocelli $1.3 \times$ as long as ocellus diameter, distance between median and lateral ocelli $0.8 \times$ as long as ocellus diameter. Eyes large, with distinct, short hairs; inner eye orbits not indented, very strongly convergent ventrad, shortest distance between eyes about as wide as first flagellomere. Gena conspicuously short and narrowed behind eyes, more shortened and narrowed towards ventral parts, in dorsal view $0.2 \times$ as long as eye width, in lateral view $0.05-0.1 \times$ as long as eye width. Occipital carina complete, little elevated, reaching hypostomal carina before base of mandible; hypostomal carina little elevated. Frons almost flat, weakly impressed above toruli. Face small, slightly convex in profile. Clypeus distinctly separated from face, small, weakly convex in profile, its apical margin weakly convex, sharp. Malar space not developed, eye reaching base of mandible. Mandible relatively long and narrow, upper mandibular tooth slightly longer and wider than lower tooth. Labial palpus with 3 segments, maxillary palpus with 4 segments. 


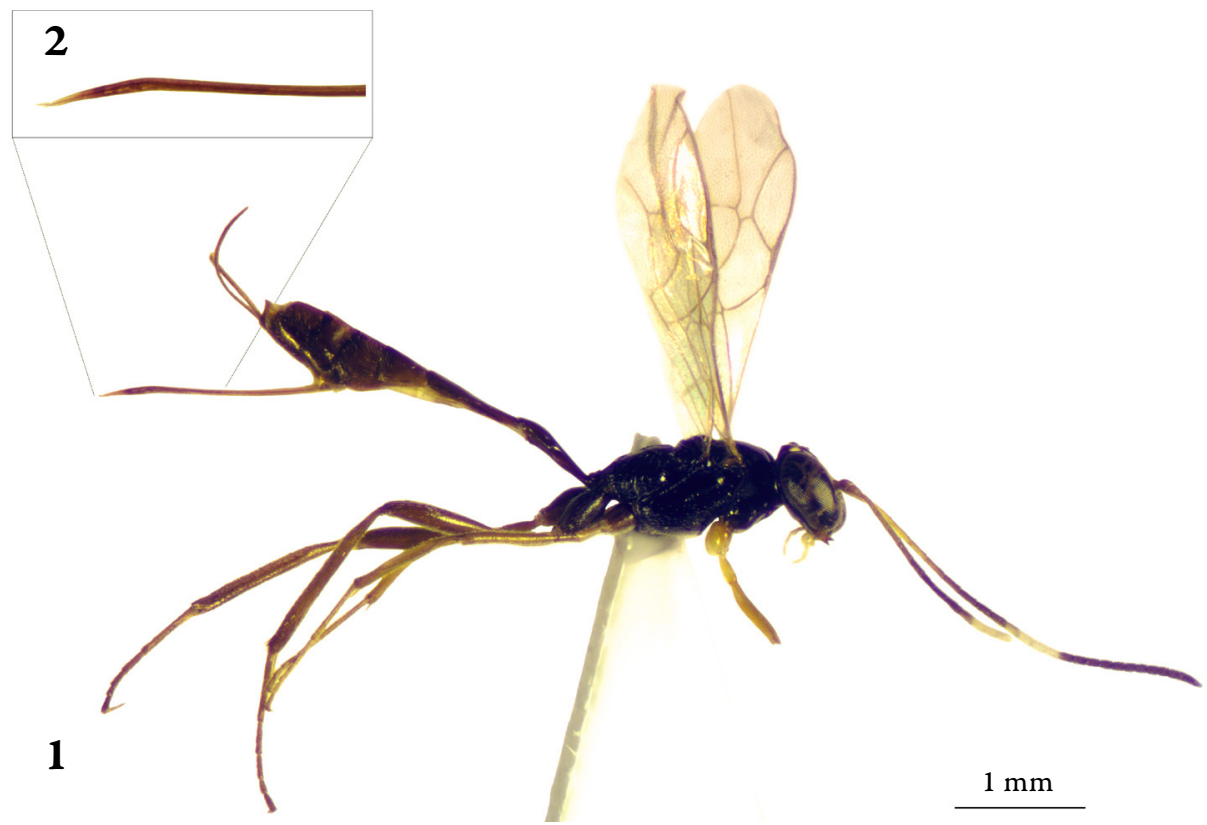

Figures 1-2. Klutiana brevigenalis sp. n., holotype. 1 = habitus, lateral view; $\mathbf{2}$ = ovipositor apex, lateral view

Mesosoma: Mesosoma moderately elongated, shiny, finely coriaceous to almost smooth, ventrolaterally and ventrally with few scattered, weak punctures, and with short, sparse hairs, hairs ventrolaterally and ventrally somewhat denser and longer. Pronotum ventrally with few transverse wrinkles; epomia distinct. Mesoscutum about as long as wide, convex in profile; notaulus strongly developed, reaching behind middle of mesoscutum. Scuto-scutellar groove wide, shallow. Scutellum convex in profile, lateral carina not developed. Mesopleuron elongated, with few weak, oblique wrinkles below speculum, speculum large and smooth. Epicnemial carina complete, little elevated, pleural part bent to anterior margin of mesopleuron reaching it below its middle height. Sternaulus anteriorly distinct but relatively weak, short, not reaching middle of mesopleuron. Posterior transverse carina of mesosternum complete, elevated. Metanotum $0.5 \times$ as long as scutellum. Metapleuron elongated; juxtacoxal carina distinct; submetapleural carina complete, elevated. Pleural carina of propodeum strong; propodeal spiracle rather small, circular, separated from pleural carina by about $1.5 \times$ its length. Propodeum little elongated, weakly convex in profile, very finely granulate, medially with transverse wrinkles, wrinkles stronger posteriorly than anteriorly. Propodeal carinae completely developed. Area basalis relatively large, about rectangular, little longer than its basal width. Area superomedia relatively small, hexagonal, apically closed, $1.5 \times$ as long as wide, its lateral sides behind 
costulae convergent; costulae connected to area superomedia before its middle. Area pleuralis $1.4 \times$ as long as area superomedia. Fore wing without areolet, $3 r s-m$ missing; second recurrent vein $(2 m-c u)$ postfurcal, intercubitus $(2 r s-m)$ about as long as abscissa of $M$ between $2 r s-m$ and $2 m-c u$, their angle acute; distal part of distal abscissa of $R s$ weakly curved toward wing margin; nervulus (cu-a) weakly antefurcal, about vertical; abscissa of $C u 1$ between $1 \mathrm{~m}$-cu and $C u 1$ a very short; lower external angle of second discal cell about right-angled; pterostigma narrow. Hind wing with nervellus ( $c u-a+$ abscissa of $C u 1$ between $M$ and $c u-a$ ) straight, reclivous, not intercepted by discoidella $(C u 1)$; discoidella spectral, proximally not connected to nervellus. Coxae granulate, fore and middle coxae finely, hind coxa more roughly. Hind femur ca. 5.5x as long as high. Inner spur of hind tibia ca. $0.4 \times$ as long as first tarsomere of hind tarsus. Tarsal claws small and thin, little longer than arolium, not pectinate.

Metasoma: Metasoma relatively short, compressed, finely granulate to shagreened, with moderately short hairs. First tergite slender, ca. $5 x$ as long as its apical width, little shorter than second tergite. Second tergite relatively stout, ca. $2.5 \times$ as long as its apical width; thyridium small, oval, situated little before mid-length. Posterior margins of apical tergites medially excised. Ovipositor sheath $0.8 \times$ as long as hind tibia; ovipositor straight, compressed, apex distinctly downcurved.

Colour: Antenna brown except scapus and pedicellus light brown, flagellomeres 1-3 yellowish brown, flagellomeres 10-12 whitish. Head black, except palpi and mandible yellowish, mandibular teeth reddish brown, clypeus partly dark brownish. Mesosoma black, except tegula brownish. Metasoma brown, first and second tergites dark brown. Wings hyaline, wing veins and pterostigma brown. Fore leg: coxa yellowish, basally brownish; trochanter and trochantellus yellowish; femur, tibia and tarsus light yellowish brown. Middle leg: coxa brown; trochanter and trochantellus yellowish brown; femur, tibia and tarsus brownish. Hind leg: coxa dark brown; trochanter, trochantellus, femur, tibia and tarsus brown.

Male: Unknown.

Distribution - Tanzania.

Etymology - The specific epithet brevigenalis is the feminine form of the Latin adjective brevigenalis, -is, -e; it refers to the conspicuously short and narrowed gena of the new species.

Remarks on identification - Klutiana hemitelina (Seyrig, 1935), the other known congeneric species of the Afrotropical region (described and known from Kenya), can be easily distinguished from the new species by the following couplet. Note that there might be not yet discovered species in the region. 
Gena conspicuously short and narrowed behind eye, more shortened and narrowed towards ventral parts, in dorsal view $0.2 \times$ as long as eye width, in lateral view $0.05-0.1 \times$ as long as eye width; second tergite stouter, ca. $2.5 \times$ as long as its apical width; ovipositor apex distinctly downcurved; metasoma and hind leg brown Klutiana brevigenalis sp. $\mathrm{n}$.

- Gena distinctly less shortened and narrowed behind eye, not further shortened and narrowed toward ventral parts, both in dorsal and lateral views $0.3-0.4 \times$ as long as eye width; second tergite distinctly slenderer, ca. $3.2 \times$ as long as its apical width; ovipositor apex almost straight, slightly sinuous, not downcurved; third tergite extensively to almost entirely orange, distinctly lighter than other tergites, hind leg except coxa lighter, extensively to almost entirely reddish Klutiana hemitelina (Seyrig, 1935)

Acknowledgements - Thanks are due to Viktória Szőke (HNHM) for post-image work, and to Filippo Di Giovanni (University of Pisa) for his valuable comments on the manuscript.

\section{REFERENCES}

GAULD I. D. 1991: The Ichneumonidae of Costa Rica, 1. Introduction, keys to subfamilies, and keys to the species of the lower Pimpliform subfamilies Rhyssinae, Poemeniinae, Acaenitinae and Cylloceriinae. - Memoirs of the American Entomological Institute 47: 1-589.

Gauld I. D., Wahl D., Bradshaw K. Hanson P. \& Ward S. 1997: The Ichneumonidae of Costa Rica, 2. Introduction and keys to species of the smaller subfamilies, Anomaloninae, Ctenopelmatinae, Diplazontinae, Lycorininae, Phrudinae, Tryphoninae (excluding Netelia) and Xoridinae, with an appendix on the Rhyssinae. - Memoirs of the American Entomological Institute 57: 1-485.

Gupta V. K. 1980: Oriental species of Klutiana (Hymenoptera: Ichneumonidae). - Oriental Insects 13: 323-339. https://doi.org/10.1080/00305316.1979.10433626

Mahunka S., Pócs T. \& Zicsi A. 1987: A report on the soil-zoological trip in Tanzania, 1987. Folia entomologica hungarica 48: 255-263.

Quicke D. L. J., Fitton M. G., Broad G. R., Crocker B., Laurenne N. M. \& Miah M. I. 2005: The parasitic wasp genera Skiapus, Hellwigia, Nonnus, Chriodes, and Klutiana (Hymenoptera, Ichneumonidae): recognition of the Nesomesochorinae stat. rev. and Nonninae stat. nov. and transfer of Skiapus and Hellwigia to the Ophioninae. - Journal of Natural History 39(27): 2559-2578. https://doi.org/10.1080/00222930500102546

Seyrig A. 1935: Mission scientifique de l'Omo. Tome III. Fascicule 18. Hymenoptera, II. Ichneumonidae: Cryptinae, Pimplinae, Tryphoninae et Ophioninae. - Mémoires $d u$ Muséum National d'Histoire Naturelle, Paris 4: 1-100.

Townes H. 1969: The genera of Ichneumonidae. Part 1. - Memoirs of the American Entomological Institute 11: 1-300. 
Townes H. 1970: The genera of Ichneumonidae. Part 3. - Memoirs of the American Entomological Institute 13: 1-307.

Townes H. \& Townes M. 1973: A catalogue and reclassification of the Ethiopian Ichneumonidae. - Memoirs of the American Entomological Institute 19: 1-416.

YU D. S. \& Horstmann K. 1997: A catalogue of world Ichneumonidae (Hymenoptera). - The American Entomological Institute, Gainesville, 1558 pp.

Yu D. S., van Achterberg C. \& Horstmann K. 2012: Taxapad 2012, Ichneumonoidea 2011. Database on flash-drive. www.taxapad.com, Ottawa.

\title{
Klutiana brevigenalis sp. n., egy tudományra új afrotropikus fürkészdarázsfaj (Hymenoptera: Ichneumonidae: Nesomesochorinae)
}

\author{
VAS ZOLTÁN \\ Magyar Természettudományi Múzeum, Állattár, H-1088 Budapest, Baross utca 13., Magyarország \\ E-mail:vas.zoltan@nhmus.hu
}

Összefoglalás - A Magyar Természettudományi Múzeum Hártyásszárnyúak gyűjteményében őrzött valódi fürkészdarazsak (Ichneumonidae) tudományos feldolgozása során a Klutiana Betrem, 1933 genusz egy tudományra új faja került elő az 1987-es tanzániai múzeumi gyűjtőút anyagából. Jelen munkában a Klutiana brevigenalis sp. n. tudományos leírását és a genusz afrotropikus fajainak határozókulcsát közli a szerző.

Kulcsszavak - taxonómia, fajleírás, Tanzánia, Magyar Természettudományi Múzeum

\section{ÁBRAMAGYARÁZATOK}

1-2. ábra. Klutiana brevigenalis sp. n., holotípus. $\mathbf{1}=$ habitus, oldalnézet; $\mathbf{2}=$ tojócső csúcsa, oldalnézet 